\title{
Expression of active trypsin-like serine peptidases in the midgut of sugar-feeding female Anopheles aquasalis
}

Geovane Dias-Lopes ${ }^{1}$, Andre Borges-Veloso ${ }^{1}$, Leonardo Saboia-Vahia ${ }^{3}$, Gilberto B. Domont ${ }^{2}$, Constança Britto ${ }^{1}$, Patricia Cuervo ${ }^{3^{*}}$ and Jose Batista De Jesus ${ }^{1,4^{*}}$

\begin{abstract}
Background: Anopheles aquasalis is a dipteran of the family Culicidae that is widely distributed in the coastal regions of South and Central America. This species acts as a vector of Plasmodium vivax, an important etiological agent of malaria, which represents a serious public health problem. In mosquitoes, trypsin-like serine proteases are important in blood meal digestion, immune responses and reproductive functions. The study of peptidases expressed in the mosquito midgut is essential to understanding the mechanisms of parasite-host interaction and the physiological process of nutrient digestion.

Methods: Our study aimed to identify and characterize the proteolytic activities in the midgut of sugar-fed An. aquasalis females using zymographic analyses (substrate-SDS-PAGE), in-solution assays and mass spectrometry.

Results: Here, we used a zymographic analysis to further biochemically characterize the proteolytic profile of the midgut of sugar-feeding An. aquasalis females. The trypsin peptidases migrated between $\sim 17$ and $\sim 76 \mathrm{kDa}$ and displayed higher proteolytic activities between $\mathrm{pH} 7.5$ and 10 and at temperatures between $37^{\circ} \mathrm{C}$ and $50{ }^{\circ} \mathrm{C}$. Four putative trypsin-like serine peptidases were identified using mass spectrometry and data mining. The molecular masses of these peptidases were similar to those observed using zymography, which suggested that these peptidases could be responsible for some of the observed proteolytic bands.

Conclusions: Taken together, our results contribute to the gene annotation of the unknown genome of this species, to the tissue location of these peptidases, and to the functional prediction of these crucial enzymes, which all impact further studies of this species.
\end{abstract}

Keywords: Anopheles aquasalis, Midgut, Zymography, Trypsin-like serine peptidases, Proteomics, Mass spectrometry

\section{Background}

Anopheles (Nyssorhynchus) aquasalis is a dipteran of the family Culicidae that is widely distributed in the coastal regions of South and Central America [1]. In these regions, this species acts as a vector of Plasmodium vivax [2, 3], an important etiological agent of malaria, which represents a serious public health problem [4-6]. The prevention of malaria transmission relies primarily on vector control strategies, which depend on the understanding of mosquito

\footnotetext{
*Correspondence: pcuervo@fiocruz.br; jbj@ioc.fiocruz.br

${ }^{3}$ Laboratório de Pesquisa em Leishmaniose - Instituto Oswaldo Cruz,

FIOCRUZ, Av. Brasil 4365, Manguinhos, Pav. 26, Sala 509, Rio de Janeiro, Brazil

'Laboratório de Biologia Molecular e Doenças Endêmicas - Instituto

Oswaldo Cruz, FIOCRUZ, Rio de Janeiro, Brazil

Full list of author information is available at the end of the article
}

biology [7-10]. Understanding the physiology and expression of specific proteins in mosquito tissues that are involved in the pathogen-host interaction can provide relevant data for developing alternative measures to control the disease [11-16]. Currently, An. aquasalis is the only Neotropical anopheline for which an experimental autonomous colony can be established [17], which allows for their use as a controlled model for various studies.

Peptidases are proteolytic enzymes that can be subdivided into endopeptidases and exopeptidases [18]. Serine peptidases are a class of endopeptidases that are characterized by the presence of three invariant residues at the active site: serine, aspartic acid and histidine $[19,20]$. In mosquitoes, serine peptidases are related primarily to 
food digestion, and blood feeding specifically regulates some of these enzymes in female adults [21-23]. In fact, this regulation is an important characteristic of hematophagic activity and is involved in host-pathogen interaction [24-26]. In Aedes aegypti, the midgut trypsin activity provides nutrients that sustain the dengue virus (DENV-2) replication and possibly act in viral surface processing, which enhances infection [27]. Experimental infections of Ae. aegypti with Plasmodium gallinaceum demonstrated that a mosquito's trypsinlike peptidase activates the parasite's prochitinase, which allows the Plasmodium to traverse through the peritrophic matrix [16]. In addition, serine peptidases are essential for mosquito immune responses, such as hemolymph coagulation, antimicrobial peptide synthesis, and the melanization of the pathogen [15, 27-29]. Furthermore, the serine peptidases of the female lower reproductive tissues of $A n$. gambiae are involved in the processing of male products transferred to females during mating [30].

Despite the availability of data on the role of serine peptidases in the mosquitoes' blood digestion, few studies have examined the active peptidases expressed in the midgut of anophelines females that feed on sugar [31-33]. Our study aimed to identify and characterize the proteolytic activities in the midgut of sugar-fed $A n$. aquasalis females using zymographic analyses (substrate-SDS-PAGE), in-solution assays and mass spectrometry. We demonstrated that sugarfeeding $A n$. aquasalis females exhibit a complex profile of trypsin-like serine peptidases with high activity in alkaline $\mathrm{pH}$, and we identified four trypsin genes that are expressed at the protein level in the midgut of the females. Given that the expression at the protein level of peptidase genes and the demonstration that they are active in female mosquitoes fed on sugar are controversial issues, our results contribute to clarifying such subjects as we characterized the active peptidases profile and identified trypsin-like serine peptidases by mass spectrometry. The role of the enzymes expressed under such conditions should be clarified in future works.

\section{Methods}

\section{Chemicals}

Stock solutions of 1,10-phenantroline (200 mM) and pepstatin A $(1 \mathrm{mg} / \mathrm{ml})$ were prepared in ethanol, whereas trans-epoxysuccinyl L-leucylamido-(4-guanidino) butane (E-64, $1 \mathrm{mM}$ ) was prepared in water. Phenyl-methyl sulfonyl-fluoride (PMSF, $250 \mathrm{mM}$ ) was diluted in isopropanol, and $\mathrm{N}$-a-Tosyl-L-lysine chloromethyl ketone hydrochloride (TLCK, $100 \mathrm{mM}$ ) and N-p-Tosyl-Lphenylalanine chloromethyl ketone (TPCK, $100 \mathrm{mM}$ ) were prepared in methanol. All protease inhibitors were maintained at $-20{ }^{\circ} \mathrm{C}$.

\section{Insects}

The experiments were conducted with female $A n$. aquasalis adults that were obtained from a colony established and maintained in the Laboratório de Fisiologia e Controle de Artrópodes Vetores of the Instituto Oswaldo Cruz (Rio de Janeiro). The mosquitoes were fed a $10 \%$ sugar solution ad libitum and maintained in laboratory conditions at $26-28{ }^{\circ} \mathrm{C}$ and $70-80 \%$ relative humidity. For each experiment, the female adults (3-5 days old) were cold-anesthetized on ice and decapitated. The midgut was dissected as previously described [34].

\section{Zymographic analysis}

Pools of 20 midguts were washed twice with phosphatebuffered saline (PBS), $\mathrm{pH} \mathrm{7.2,} \mathrm{and} \mathrm{homogenized} \mathrm{in} \mathrm{lysis}$ buffer containing $10 \%$ glycerol, $0.6 \%$ Triton X-100, $100 \mathrm{mM}$ Tris- $\mathrm{HCl} \mathrm{pH} \mathrm{6.8,} \mathrm{and} 150 \mathrm{mM} \mathrm{NaCl}$ [35]. The homogenates were centrifuged at $14,000 \times g$ and $4{ }^{\circ} \mathrm{C}$ for $30 \mathrm{~min}$ to remove insoluble material, and the proteins were resolved as previously described [36]. Briefly, the supernatants were mixed with sodium dodecyl sulfate polyacrylamide gel electrophoresis (SDS-PAGE) sample buffer (125 mM Tris, pH 6.8, 4 \% SDS, 20 \% glycerol, $0.002 \%$ bromophenol blue) and loaded onto $10 \%$ SDSPAGE co-polymerized with $0.1 \%$ porcine gelatin. The gels were loaded with $5 \mu \mathrm{g}$ of protein per well, and electrophoresis was carried out at $4{ }^{\circ} \mathrm{C}$ with a constant voltage of $110 \mathrm{~V}$. Subsequently, the gels were washed twice for $30 \mathrm{~min}$ at $4{ }^{\circ} \mathrm{C}$ in either $100 \mathrm{mM}$ sodium acetate buffer $(\mathrm{pH} 3.5$ or 5.5$)$ containing $2.5 \%$ Triton X-100 or $100 \mathrm{mM}$ Tris- $\mathrm{HCl}$ buffer (pH 7.5 or 10.0) plus $2.5 \%$ Triton X-100. The protease activities were detected by incubating the gels in a reaction buffer containing $100 \mathrm{mM}$ sodium acetate $(\mathrm{pH} 3.5$ or 5.5$)$ or $100 \mathrm{mM}$ Tris- $\mathrm{HCl}$ buffer (pH 7.5 or 10.0) at $37{ }^{\circ} \mathrm{C}$ for $30 \mathrm{~min}, 2$, 4 , and $6 \mathrm{~h}$. The hydrolyzed gelatin bands were visualized by staining the gels in a solution of $0.2 \%$ Coomassie blue R-250, $40 \%$ methanol, and $10 \%$ acetic acid and destaining them with $10 \%$ acetic acid. The molecular masses of the peptidases were estimated by comparing them with the mobility of molecular mass standards (PageRuler $^{\mathrm{Tm}}$ Protein Ladder, Fermentas). All results are derived from three independent experiments carried out in triplicate.

\section{Effect of temperature and peptidase inhibitors on proteolytic activity}

After the electrophoresis, gels of female midgut homogenates were incubated at $10,25,37,50,65$ and $80{ }^{\circ} \mathrm{C}$ for $2 \mathrm{~h}$ in preheated $100 \mathrm{mM}$ Tris- $\mathrm{HCl} \mathrm{pH} 7.5$ reaction buffer. The peptidases were resolved as described above. To analyze the sensitivity of peptidases to inhibitors, the female midgut homogenates were pre-incubated (before electrophoresis) for $30 \mathrm{~min}$ at $37{ }^{\circ} \mathrm{C}$ with one of the 
following peptidase inhibitors: $10 \mu \mathrm{M}$ E-64, $1 \mathrm{mM}$ PMSF, $100 \mu \mathrm{M}$ TLCK, $100 \mu \mathrm{M}$ TPCK, $10 \mu \mathrm{M}$ pepstatin-A, or $10 \mathrm{mM}$ 1,10-phenanthroline. These inhibitors were also added to the reaction buffer at the same concentration. The peptidase activities were resolved as described above.

\section{In-solution enzymatic assays}

The in-solution assays were performed at $37{ }^{\circ} \mathrm{C}$ and $\mathrm{pH} 7.5$ using the fluorogenic substrate Z-carbobenzoxyL-phenylalanyl-L-arginine-(7-amino-4-methylcoumarin)

[Z-Phe-Arg-AMC]. The substrate was prepared at a concentration of $3 \mathrm{mM}$ in dimethyl sulfoxide (DMSO) and diluted to a $100 \mu \mathrm{M}$ working concentration for each assay. The reactions proceeded by adding $5 \mu \mathrm{g}$ of proteins from the female midgut diluted in $100 \mathrm{mM}$ sodium acetate (at pH 3.5 or 5.5) or $100 \mathrm{mM}$ Tris- $\mathrm{HCl}$ (pH 7.5 or 10.0) for $\mathrm{pH}$ evaluation or peptidase inhibitors: $10 \mu \mathrm{M}$ E-64, $1 \mathrm{mM}$ PMSF, $100 \mu \mathrm{M}$ TLCK, $100 \mu \mathrm{M}$ TPCK. The fluorescence intensity was measured continuously by spectrophotofluorometry for a $45 \mathrm{~min}$ period (Molecular Devices) using excitation and emission wavelengths of 380 and $460 \mathrm{~nm}$, respectively. All assays were performed at $37{ }^{\circ} \mathrm{C}$. Controls without enzyme or without substrate were also included. All results are derived from three independent experiments carried out in triplicate.

\section{Protein extraction and mass spectrometry analysis}

Fifty pooled midguts were mechanically disrupted with a pestle and a motor drive in $100 \mu \mathrm{L}$ of lysis buffer $(2 \mathrm{M}$ Thiourea, 7 M Urea, 4 \% CHAPS and 65 mM DTT) and a protease inhibitor cocktail. To remove the insoluble material, the samples were centrifuged at $14,000 \times g$ for $15 \mathrm{~min}$ at $4{ }^{\circ} \mathrm{C}$. Subsequently, the samples were precipitated with a 3:1 solution of methanol:chloroform. The proteins were re-suspended in buffer containing $0.5 \mathrm{M}$ Hepes and $7 \mathrm{M}$ urea, and the protein concentration was determined using Qubit. The proteins were enzymatically digested in a solution following previously established protocols [37] with some modifications. Briefly, the proteins were reduced in $65 \mathrm{mM}$ DTT for $30 \mathrm{~min}$ at $56{ }^{\circ} \mathrm{C}$ and then alkylated with $200 \mathrm{mM}$ iodoacetamide at $25{ }^{\circ} \mathrm{C}$ in the dark for $30 \mathrm{~min}$. Trypsin (200 ng) was added, and the mixture was incubated at $37{ }^{\circ} \mathrm{C}$ overnight. The peptides were purified and concentrated using a column packed in-house with Poros oligo R3 resin (Applied Biosystems). The peptides were finally eluted with a solution of $0.1 \%$ formic acid in $50 \% \mathrm{v} / \mathrm{v}$ acetronitrile. Three biological replicates were performed in technical triplicates.

For each sample, $4 \mu \mathrm{L}$ of peptides were applied to an EASY II-nano LC system (Thermo Fisher Scientific) coupled online to an ESI-LTQ-Orbitrap Velos mass spectrometer (Thermo Fisher Scientific). The peptides were eluted through a trap column $(150 \mu \mathrm{m} \times 2 \mathrm{~cm})$ packed in-house with C-18 ReproSil $5 \mu \mathrm{m}$ resin and an analytical column $(100 \mu \mathrm{m} \times 15 \mathrm{~cm})$ packed in-house with C-18 ReproSil $3 \mu \mathrm{m}$ resin. Mobile phase A consisted of $0.1 \%(\mathrm{v} / \mathrm{v})$ formic acid in water, and mobile phase B consisted of $0.1 \%(\mathrm{v} / \mathrm{v})$ formic acid in acetonitrile. The gradient conditions were as follows: 5-40 \% $\mathrm{B}$ in $180 \mathrm{~min}$. Mass spectra were acquired in positive mode using the data-dependent automatic (DDA) survey MS scan and tandem mass spectra (MS/MS) acquisition. Each DDA consisted of a survey scan of the $\mathrm{m} / \mathrm{z}$ range of 300-2000 and resolution of 60000 with a target value of $1 \times 10^{-6}$ ions. Survey scan was followed by the MS/ MS of the 10 most intense ions in the LTQ using the collision-induced dissociation (CID), and previously fragmented ions were dynamically excluded for $60 \mathrm{~s}$.

\section{Protein identification}

The data were searched using the ProLuCID 1.3 search engine in the PatternLab platform [38] against a customized database that included non-redundant sequences of the Culicidae family retrieved from UniRef100 (approximately 81,000 entries, downloaded June 2014, http:// www.uniprot.org/). Searches were performed with one missed cleavage, with the carbamidomethylation of cysteine residues as a fixed modification, methionine oxidation as a variable modification and mass tolerances of $50 \mathrm{ppm}$ and $500 \mathrm{ppm}$ as precursor and fragment ions, respectively. The false discovery rate (FDR) was estimated using the identifications obtained with the reversed decoy database. The validity of the peptide sequence matches (PSMs) was assessed using the Search Engine Processor (SEPro) of the PatternLab platform [39]. This software uses the XCorr, DeltaCN and ZScore values from the ProLuCID analysis to create a discriminator score. The peptide identification was based on a false-discovery rate (FDR) of $1 \%$ and post-processed to only accept PSMs mass tolerances less than $10 \mathrm{ppm}$. The protein identification is supported by at least two independent pieces of evidence: (i) the identification of a peptide with different charge states; (ii) a modified and a non-modified version of the same peptide; (iii) more than two spectra for peptide; or (iv) two different peptides.

\section{Multiple sequence alignment analysis}

The amino acid sequences of trypsin peptidases identified by MS/MS were aligned using CLUSTAL Omega [40] against the well-annotated sequences of Ae. aegypti trypsin 3 (TRY3_AEDAE) and An. gambie trypsin 6 (TRY6_ANOGA). The trypsin sequences were scanned for the active site (His, Asp, Ser), the signal peptide and the conserved cysteine residues of disulfide bounds 
using the PROSCAN function of the PROSITE suite (http://prosite.expasy.org) [41]. The signal peptide was also predicted by SignalP 4.0 (http://cbs.dtu.dk/services/ SignalP) [42].

\section{Results}

Time course of proteolytic activities in the midgut of $A n$. aquasalis females

To evaluate the influence of the reaction time on the proteolytic activity of the midgut from An. aquasalis females, the gels were incubated for $30 \mathrm{~min}, 2,4$ and $6 \mathrm{~h}$ in $100 \mathrm{mM}$ Tris- $\mathrm{HCl}$ reaction buffer $(\mathrm{pH} 7.5)$ at $37^{\circ} \mathrm{C}$ (Fig. 1). The intensity of the proteolytic activity progressively increased up to $6 \mathrm{~h}$. After $2 \mathrm{~h}$ of reaction, the proteolytic profile consisted of at least seven bands ranging from $\sim 17$ to $\sim 76 \mathrm{kDa}$. At 4 and $6 \mathrm{~h}$, the intense enzymatic activity led to the overlapping of the bands, which precluded the analysis. Thus, the enzymatic reaction time was limited to $2 \mathrm{~h}$ for the subsequent analyses.

\section{Effect of $\mathrm{pH}$ on the proteolytic profile of the midgut of An. aquasalis females}

To determine the effect of the $\mathrm{pH}$ on the proteolytic activity, the gels were incubated for $2 \mathrm{~h}$ in reaction buffer at $\mathrm{pH} 3.5,5.5,7.5$ or 10 . The enzymatic activities were detected at all tested $\mathrm{pH}$ values and progressively

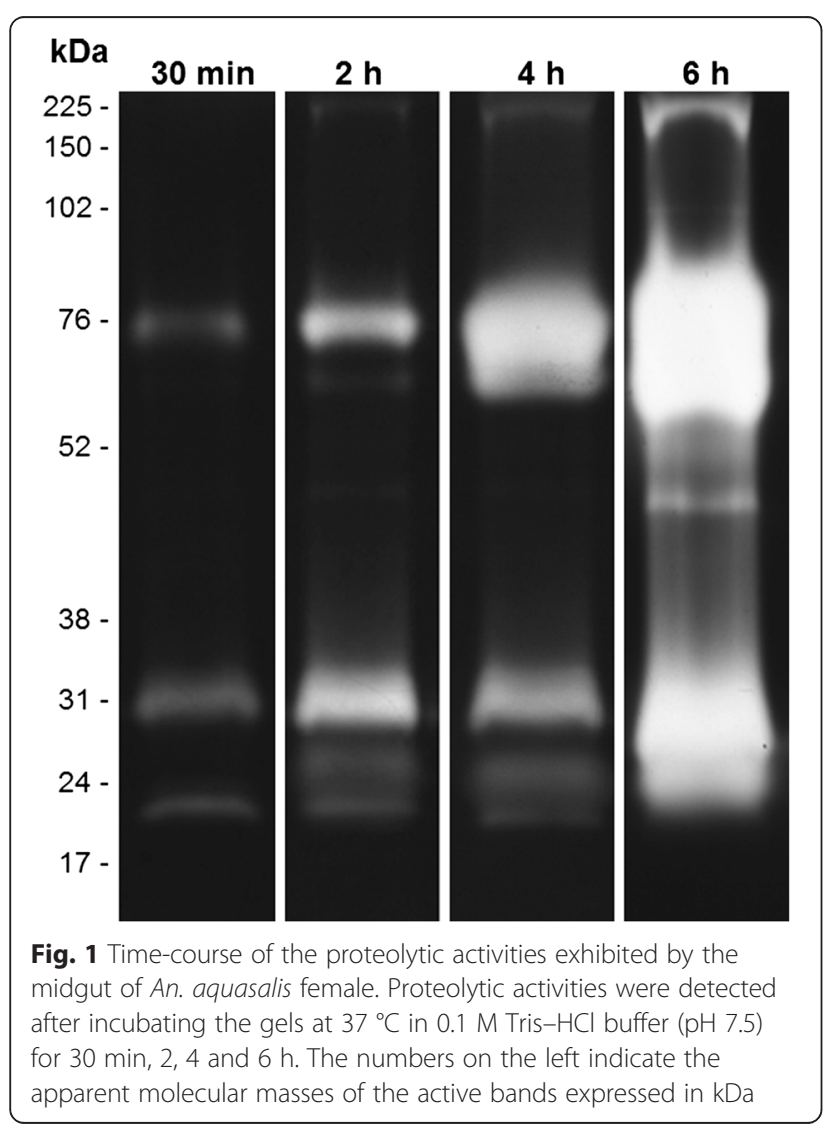

increased from pH 3.5 to 10 (Fig. 2). At pH 3.5 and 5.5, only a few bands were detected. These bands were less intense than the bands obtained at $\mathrm{pH} 7.5$ and 10. At $\mathrm{pH} 10$, the intense proteolytic activity hampered the resolution of the profile. Thus, the proteolytic profile was better resolved at $\mathrm{pH} 7.5$.

Influence of temperature and peptidase inhibitors on the proteolytic profile of the midgut of An. aquasalis females The thermal sensitivity of the enzymatic activity of female midguts was evaluated by incubating the gels for $2 \mathrm{~h}$ at 10 , $25,37,50,65$ or $80{ }^{\circ} \mathrm{C}$ in $100 \mathrm{mM}$ Tris- $\mathrm{HCl}$ reaction buffer at pH 7.5 (Fig. 3). The enzymatic activity at 10 and $25^{\circ} \mathrm{C}$ was low compared with that observed at $37^{\circ} \mathrm{C}$. The activity strongly increased at $50{ }^{\circ} \mathrm{C}$ and then decreased at $65{ }^{\circ} \mathrm{C}$ and $80{ }^{\circ} \mathrm{C}$. The proteolytic profile exhibited by the midgut of females was strongly inhibited by $1 \mathrm{mM}$ PMSF and $100 \mu \mathrm{M}$ TLCK. However, $100 \mathrm{mM}$ TPCK did not affect the proteolytic activity (Fig. 4). The activities were not inhibited by $10 \mathrm{mM}$ E-64, $10 \mathrm{mM}$ pepstatin A, or $10 \mathrm{mM}$ 1,10-phenanthroline (data not shown). These results demonstrate that the trypsin-like serine peptidases are responsible for the observed activity.

\section{In-solution enzymatic assays}

The effects of the peptidase inhibitors and $\mathrm{pH}$ on the proteolytic activities of midgut homogenates were also

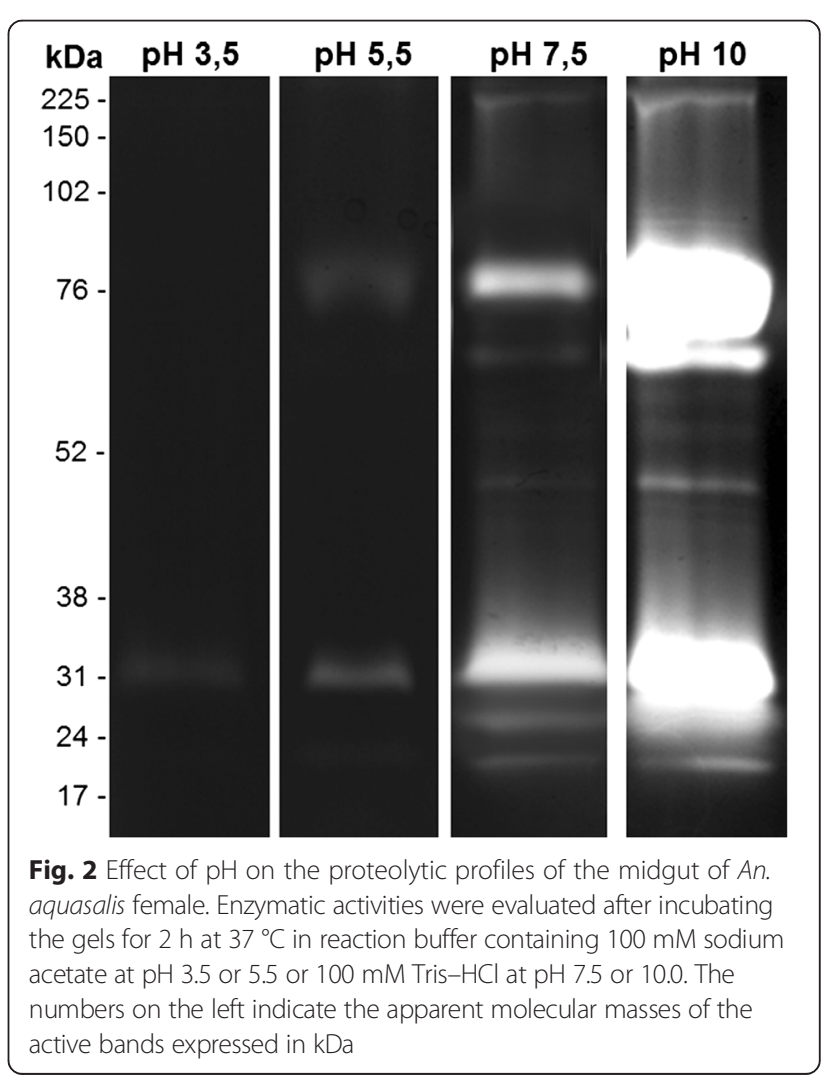



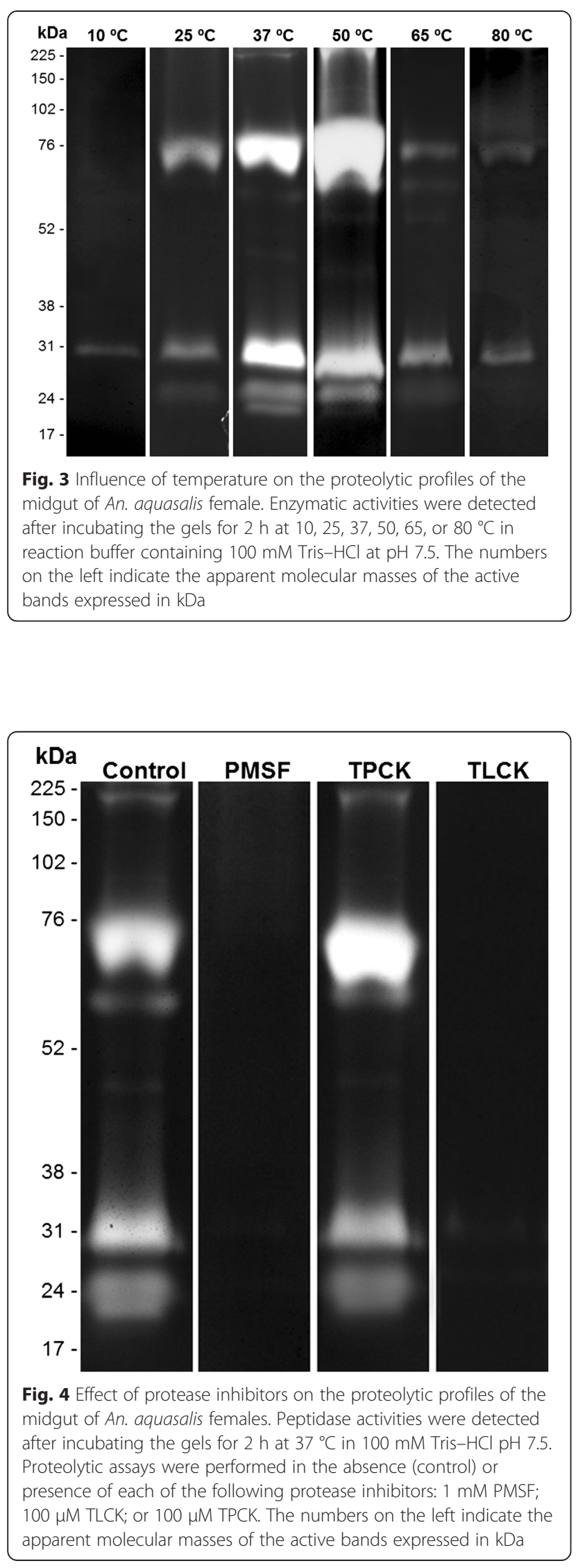

evaluated by in-solution assays using the fluorogenic substrate Z-Phe-Arg-AMC (Fig. 5). PMSF and TLCK, but not TPCK, strongly inhibited these activities, which corroborated the in-gel results (Fig. 5a). In addition, enzymatic activity was detected at all of the tested $\mathrm{pH}$ values, and this activity progressively increased from $\mathrm{pH} 3.5$ to 10 . At $\mathrm{pH} 7.5$ and 10, the hydrolysis of the substrate reached a plateau after 15 min of reaction and remained stable until the final reaction time of $45 \mathrm{~min}$ (Fig. 5b).

\section{Identification of trypsin-like serine peptidases using mass spectrometry}

Four trypsin peptidases were identified in the midgut of sugar-fed females of An. aquasalis using mass spectrometry (Table 1). These peptidases were identified by matching them to the An. aquasalis sequences in the UniRef100 database. The molecular masses of the peptidases identified by MS ranged from 29 to $33 \mathrm{kDa}$. In addition, the peptide sequences identified by MS/MS for each peptidase were different. All identified trypsin proteins matched the An. aquasalis protein sequences. An analysis of the alignment of the amino acid sequence of these peptidases showed the following: (i) the conserved amino acid residues of the catalytic triad (His, Asp and Ser); (ii) the six cysteine residues involved in the disulfide bonds; (iii) the signal peptide sequence; and (iv) the putative autocatalytic activation motifs immediately after an arginine or lysine residue (R/K- IVGG) (Fig. 6).

\section{Discussion}

Information on the serine peptidase expression in $A n$. aquasalis is scarce, and only two studies have described the identification of two blood-induced trypsins (AnaqTryp-1 and AnaqTryp-2) [43] and two chymotrypsins (Anachy1 and Anachy2), which were detected $24 \mathrm{~h}$ after the ingestion of blood [44]. In addition, the characterization of one transcript that codes for a chymotrypsin-like peptidase of $A n$. aquasalis expressed after infection with $P$. vivax has been reported [45]. Differences in the expression of distinct serine peptidase-coding transcripts during the different developmental stages of An. aquasalis and between sugarand blood-feeding females have been described [46]. In this work, we demonstrated the activity of trypsin-like serine peptidases in the midgut of sugar-feeding females and identified, by MS/MS, peptidases with molecular masses similar to those observed in the zymography, which suggested that these peptidases could be responsible for some of the observed proteolytic bands.

The epithelial cells of the midgut of anopheline mosquitoes release apical vesicles into the midgut lumen upon blood feeding. These vesicles contain trypsins and peritrophic matrix proteins, such as perithrofin 1, which are crucial for food digestion [47]. Because the stretching of 


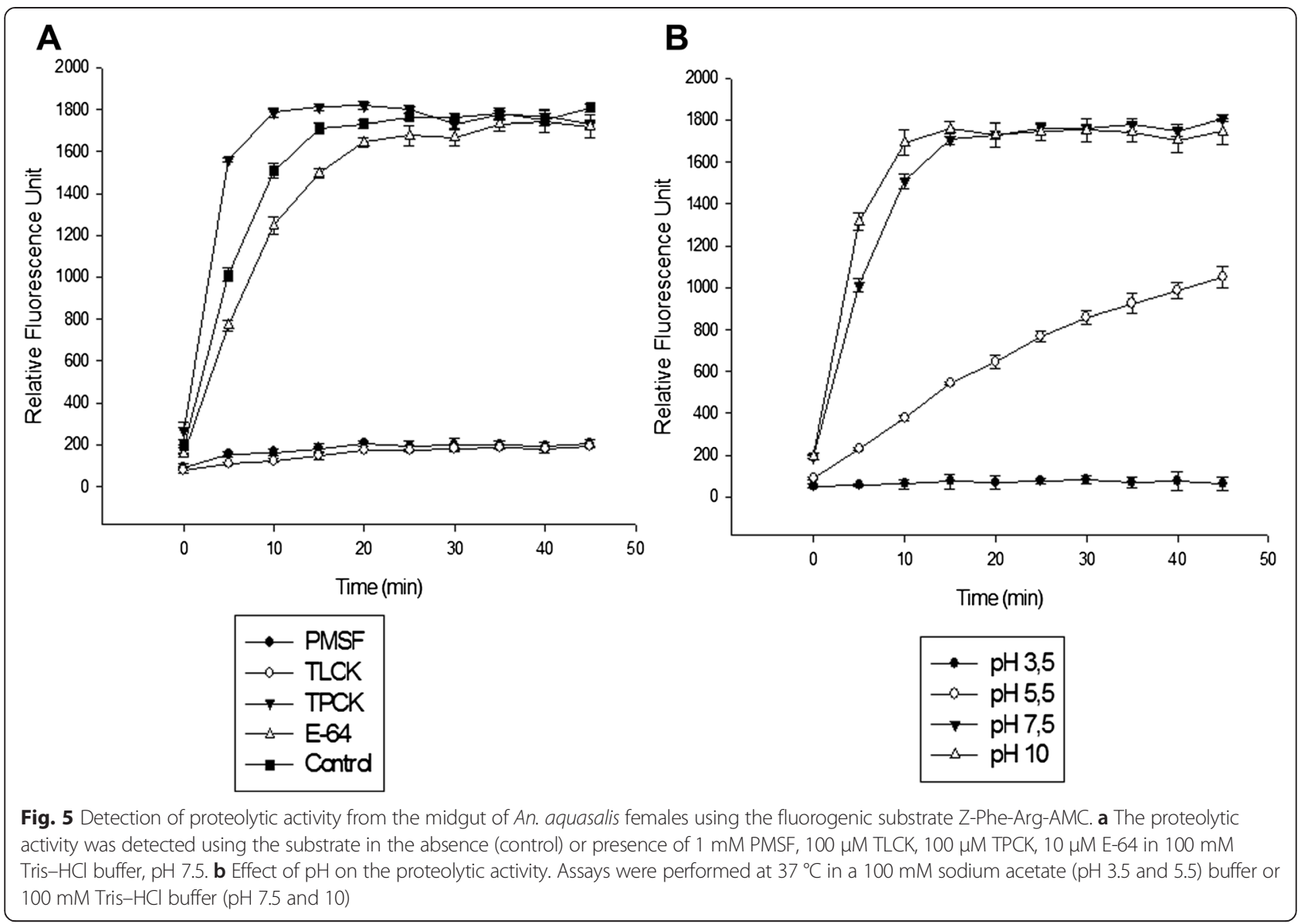

the gut is the main stimulus for the release of these vesicles, even the intake of sugar promotes their release [32]. If trypsin peptidases released from vesicles find their substrate, the small peptides or free amino acids produced are the signal responsible for the transcription and translation of other genes related to digestion [32]. In fact, the trypsin genes of An. gambiae and An. stephensi contain putative trypsin regulatory elements (PTRE) that can bind to two distinct nuclear protein complexes responsible for the transcriptional regulation of early and late trypsins [48]. In Ae. aegypti, the early trypsin gene is transcribed before the blood meal, but its translation depends on the intake of blood [49]. The digestion of saline or sugar solutions cannot stimulate the translation of early trypsin; only the intake of amino acids is a sufficient stimulus. Amino acids have been demonstrated to be capable of inducing gene translation via the activation of the TOR kinase pathway [50]. Our study identified four trypsin-like serine peptidases and one peritrophin (Putative peritrophin-1 - data not shown) by MS/MS, which supported the expression of such proteins in females that fed on sugar.

An analysis of the transcriptome of sugar-fed $A n$. aquasalis females revealed the expression of trypsin-like peptidases. These enzymes have been suggested to be involved in the initial steps of blood digestion or could be related to the regulation of other trypsin genes [46]. Similarly, early works showed that An. gambiae expresses a cluster of seven trypsin genes, among which antryp1 and antryp2 are induced after blood feeding, while antryp3, antryp 4 and antryp 7 are constitutively expressed and undetectable after blood feeding. The antryp 1 and antryp 4 zymogens are present in the apical vesicles of female midgut prior to a blood meal [33, 51]. These zymogens are activated during their secretion into the midgut lumen [47], likely via an auto-activation mechanism [33]. In agreement with these observations, we detected a high proteolytic activity in a short reaction time in An. aquasalis females that fed on sugar. In addition, our results show a drastic difference in the trypsin activity profile among Culicidae members fed on sugar [52]. These findings could suggest the existence of distinct mechanisms of trypsin regulation in such mosquito species. Together with fluid reduction via diuresis, which is mainly responsible for the mosquito body weight reduction after blood feeding, the high level of trypsins continuously expressed in the midgut of anopheline females may allow the mosquitoes to immediately digest the protein input, contributing also for the rapid 
Table 1 Anopheles aquasalis midgut trypsins identified using the ProLuCID and SEPro software

\begin{tabular}{|c|c|c|c|c|c|c|c|}
\hline ID & Peptides & Length & MolWt (MH) & SeqCount & SpecCount & Coverage & Description \\
\hline \multirow[t]{11}{*}{ T1DJF4 } & & 314 & 33666,9 & 11 & 175 & 0,27 & Putative trypsin-like serine protease Anopheles aquasalis \\
\hline & \multicolumn{7}{|c|}{ R.EWIREVSQV.- } \\
\hline & \multicolumn{7}{|c|}{ R.VALAREWIREVSQV.- } \\
\hline & \multicolumn{7}{|c|}{ R.ATFVPILAQSDCER.A } \\
\hline & \multicolumn{7}{|c|}{ R.AGSSFRNRGDDIHRSERWEHPDYDPETTDFDYALIELASPLELDGLTKR.A } \\
\hline & \multicolumn{7}{|c|}{ R.WEHPDYDPETTDFDYALIELASPLELDGLTKR.A } \\
\hline & \multicolumn{7}{|c|}{ R.VLRATFVPILAQSDCER.A } \\
\hline & \multicolumn{7}{|c|}{ R.VALAREWIR.E } \\
\hline & \multicolumn{7}{|c|}{ R.AGSSFRNRGDDIHR.S } \\
\hline & \multicolumn{7}{|c|}{ R.ATFVPILAQSDCERAYSK.I } \\
\hline & \multicolumn{7}{|c|}{ R.VLRATFVPILAQSDCERAYSK.I } \\
\hline \multirow[t]{2}{*}{ T1EA52 } & & 290 & 31253,4 & 1 & 23 & 0,05 & Putative serine protease Anopheles aquasalis \\
\hline & \multicolumn{7}{|c|}{ R.VSSFIDWINDKLNN.- } \\
\hline \multirow[t]{9}{*}{ T1DEY9 } & & 281 & 30124 & 8 & 99 & 0,37 & Putative trypsin-3 Anopheles aquasalis \\
\hline & \multicolumn{7}{|c|}{ R.DWIRQNSGV.- } \\
\hline & \multicolumn{7}{|c|}{ R.YGSSEHAAGGTLVPVAR.I } \\
\hline & \multicolumn{7}{|c|}{ D.PVEDTTLCKVSGWGNTQSVSESTKTLR.A } \\
\hline & \multicolumn{7}{|c|}{ R.VASARDWIRQNSGV.- } \\
\hline & \multicolumn{7}{|c|}{ R.ATYVPSVNQDECR.K } \\
\hline & \multicolumn{7}{|c|}{ R.FGSHNCGGSIISKEWVLTAAHCTVGASPSSLAVRYGSSEHAAGGTLVPVAR.I } \\
\hline & \multicolumn{7}{|c|}{ K.TLRATYVPSVNQDECR.K } \\
\hline & \multicolumn{7}{|c|}{ R.FGSHNCGGSIISKEWVLTAAHCTVGASPSSLAVR.Y } \\
\hline \multirow[t]{7}{*}{ T1DN08 } & & 278 & 29534,6 & 5 & 117 & 0,14 & Putative trypsin-1 Anopheles aquasalis \\
\hline & \multicolumn{7}{|c|}{ R.VASVRDWIRQNSGV.- } \\
\hline & \multicolumn{7}{|c|}{ R.DWIRQNSGV.- } \\
\hline & \multicolumn{7}{|c|}{ R.YGSSEHAAGGTLVPVAR.V } \\
\hline & \multicolumn{7}{|c|}{ K.AGYPGVYAR.V } \\
\hline & \multicolumn{7}{|c|}{ R.VASVRDWIR.Q } \\
\hline & \multicolumn{7}{|c|}{ R.VASVRDWIR.E } \\
\hline
\end{tabular}

reduction in body weight that would be important for females quick dispersion and oviposition as well as for host-seeking [31].

The molecular weight of trypsins found in the midgut of mosquitoes ranges from 20 to $35 \mathrm{kDa}$ [23]. In agreement with this description, the masses of the four trypsin peptidases identified here by mass spectrometry ranged from 29 to $33 \mathrm{kDa}$. However, the zymographic assays indicated bands migrating between $\sim 17$ to $\sim 76 \mathrm{kDa}$. The higher molecular mass bands could be due to the sample preparation procedure, in which the proteins are not completely denatured and reduced, enabling protein aggregation and/or oligomerization that slows the electrophoretic migration; therefore, the apparent molecular mass of peptidases may increase in the zymographic gel. Despite this possibility, the zymographic profiles observed here are highly reproducible and agree with previous reports of high molecular mass peptidase activities detected by zymographic methods [26, 52-56].

The $\mathrm{pH}$ of the midgut lumen is alkaline and can directly modulate the enzymatic activity [23]. The maintenance of the $\mathrm{pH}$ is attributed to the presence of proton pumps in the intestinal epithelium [57] and the enzyme carbonic anhydrase [58]. In the posterior midgut, where the blood is stored, peritrophic membrane proteins and digestive enzymes are secreted for the digestive process [59]. The $\mathrm{pH}$ of the posterior midgut of Ae. aegypti adult females ranges from 8.5 to 9.5 , whereas it ranges from 8.0 to 9.5 in An. gambiae [58]. In agreement with these observations, our zymographic results showed that the proteolytic activity is higher at $\mathrm{pH} 7.5$ and 10 . These findings were also verified during the in-solution assays.

The serine peptidases of Ae. aegypti [55], Oestrus ovis [60] and the coleoptera Tenebrio molitor larvae [61, 62] 
T1DJF4 ANOAQ ILWIIKLSYL--RDNSVIFLESSKPTTIGGPSGAELQSKPILETVDPMAKLFLLAACALL 58 TIEA52_ANOAQ TIDEY9_ANOAQ TIDNO8_ANOAQ TRY 6 AN $O G A$ TRY3_AEDAE

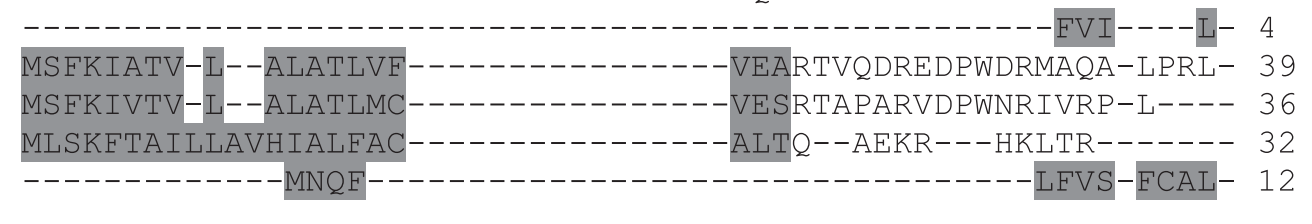

0

TIDJF4 ANOAQ IAATAVSGRAAAGGADPRGRRRAGQIVGGFAIDITDAPYQVALLHN-------GRFDCGG 111 T1EA52 ANOAQ ---------LALVALAAAKPSSTRIVGGENAIEHEFPYQISLQINYHKPGRAPFHFCGG 54 TIDEY9 ANOAQ ---------PRLPQEPRYVSKGNRIVGGFAIDISEAPYQVSLQRF-------GSHNCGG 82 T1DN08 ANOAQ ---------PRLPQGSRYVSGGNR IVGGEAIDISEAPYQVSLQHR-------GSHNCGG 79 TRY 6 ANNOGA --------PAF-HPNAPYLAGKR IVGGFVIDISDAPYQISLQYN-------GKHHCGG 74 TRY3_AEDAE ---------LGLSQVSAATLSSGR IVGGFQIDIAEVPHQVSLQRS-------GRHFCGG 55

*O

T1DJF4 ANOAQ SIISPNWILTAAHCTHGIPSRELSVRAGSSFRN--------RGDD----------- 148 T1EA52 ANOAQ SLIAERFVLTAAHCVPQDVPAGAVPEAVAGEHDFRDCTGRDVLGDTVSSSQHEAVAGEHD 114 TIDEY9_ANOAQ SIISKEWVLTAAHCTVGASPSSLAVRYGSSEHA--------AGGT------------ 119 T1DN08_ANOAQ SIIASKWVLTAAHCTAGASPSSLAVRYGSSEHA---------AGGT-------------- 116 TRY 6 AÑNA TRY3_AEDAE SILNSKWILTAAHCIDLYSEVKPTVRVGSSEHA---------AGGT------------- 111

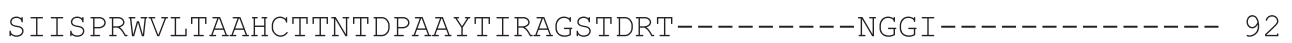

TIDJF4 ANOAQ --------IHRSERVVEHPDYDPETTDFDYALIELASPLELDGLTKRAIELQHEDDTGP 199 T1EA52_ANOAQ FTQFDESVQRRAIVEFIVHEGYSGGIGPNDIAVFRVDRPFHLNRNV-QLINLPEPEA--- 170 TIDEY 9 ANOAQ --.---LVPVARI INHPKYNGNTISYDFSLLQLKQEVVFGEDA-QPVDLPE-QDDPV 168 TIDNO8_ANOAQ TRY 6 AN $O G A$ TRY3_AEDAE --------LVPVARVVSHPKYDGSTISYDFSLLELEEAIHFSDKA-QSVDLPE-QNEPV 165 --------VLHLLRIVPHPGHSSGGNNYDIALLELECELTENDNV-QPVQLPE-QDDPI 160 --------IVKVKSVIPHPQYNGDTYNYDFSLLELDESIGFSRSI-EAIALPE-ASETV 141

0 0

T1DJF4_ANOAQ EEDEQAMVSGWGATKD--RYTSNRVLRATFVPILAQSDCERAYSKIGTGLITENMLCAGY 257 TIEA52_ANOAQ SPNGLCIISGWGSTSFSPFPTYPSILQKTTIPIFDLEECREIYHTQ---NIADSNICAGT 227 TIDEY9-ANOAQ EDTTLCKVSGWGNTQS--VSESTKTLRATYVPSVNQDECRKAYASFG--GITETMLCAGF 224 T1DNO 8-ANOAQ EDATLCKVSGWGNTQN--WSESTKLLRAANVPTVNQSECQEAYADFG--GITDTMLCAGY 221 TRY 6 AN̄OGA TRY3_AEDAE DEGTMGIVSGWGMTMS--AADLNAILRATNVPTVNQQECNQAYQSYG--GVAEQMFCAGY 216 ADGAMCTVSGWGDTKN--VFEMNTLLRAVNVPSYNQAECAAALVNVV--PVTEQMICAGY 197

$$
\S \circ \#^{*} \quad \S \quad 0 \quad \S
$$

T1DJF4 ANOAQ YYGGHDSCQGDSGGPLVVDD-----VQVGVVSWG-SGCGVATLPGVYARVALAREWIREV 311 T1EA52_ANOAQ IEGSSSVCSGDSGGPLVQIEYDGSFVQVGTVSWGGIPCGGYRNPGVFVRVSSFIDWINDK 287 TIDEY9-ANOAQ KNGGKDACQGDSGGPLVAND-----QLIGVVSWG-YGCAVPGFPGVYARVASARDWIRQN 278 T1DN08_ANOAQ KNGGKDACQGDSGGPLYANQ-----KLVGVVSWG-YGCAKAGYPGVYARVASVRDWIRQN 275 TRY 6 AN TRY3_AEDAE KQGGTGTCRNDSGGPFVAEG-----KLIGVVSWS-HECALAGYPGVYARVASVRDWIRET 270 AAGGKDSCQGDSGGPLVSGD-----KLVGVVSWG-KGCALPNLPGVYARVSTVRQWIREV 251

TIDJF4_ANOAQ SQV 314 TIEA52 ANOAQ LNN 290 T1DEY9 ANOAQ SGV 281 TIDNO8 ANOAQ SGV 278 TRY6_ANNOGA SGV 273 TRY3_AEDAE SEV 254

Fig. 6 Alignment of An. aquasalis trypsin sequences identified by MS/MS with well annotated trypsin sequences (trypsin-3 of Ae. aegypti and trypsin-6 of An. gambiae). Regions of importance are represented as follows: (Gray) signal peptide; (Italic and bold) N-terminal residues of the active enzyme; (O) conserved cysteine of disulfide bonds; $\left(^{*}\right)$ conserved catalytic triad; (§) accessory catalytic residues; (\#) highly conserved Asp 194 
are reportedly thermally sensitive. We observed that the trypsin-like serine peptidases of An. aquasalis are active over a large temperature range, but the proteolytic activity is markedly decreased at lower temperatures. These findings are in agreement with that observed in O. ovis [60]. The authors of this previous study suggested that these enzymes could be partially inactivated at low temperatures, which could affect the degradation of food in the larval stages and culminate in the low rates of larval development that are characteristic of the cold months in temperate climates [60]. The possibility that these enzymes retain some level of activity at low temperatures may have ecological implications in mosquitoes, such as during diapause, as suggested by other authors [63].

\section{Conclusion}

The study of peptidases expressed in the mosquito midgut is essential to understand the mechanisms of parasite-host interaction and the physiological process of nutrient digestion. Here, we biochemically characterized the active proteolytic profile of An. aquasalis and confirmed the expression of four putative trypsin-like serine peptidases of similar molecular mass as those observed with zymography. These findings contribute to the gene annotation of the unknown genome of this species, to the tissue location of these peptidases, and to the prediction of the function of these crucial enzymes, impacting further studies of this species.

\section{Competing interests}

The authors declare that they have no competing interests.

\section{Authors' contributions}

$J B J, G D L$ and PC designed the study. GDL, LSV, ABV and performed the experimental work. GDL, PC and JBJ analyzed the data and prepared the manuscript with the critical input of CB and GBD. All authors read and approved the final manuscript.

\section{Acknowledgements}

This work was supported by FAPEMIG (Edital Universal Process No. APQ-01070-12), FIOCRUZ-IOC, CNPq (J.B.J. PQ Process No. 308679/2012-1) and CAPES. We thank Prof. Dr. José Bento Pereira Lima and Denise Valle (Laboratório de Fisiologia e Controle de Artrópodes Vetores of the Instituto Oswaldo Cruz) for kindly providing the insects.

\section{Author details \\ 'Laboratório de Biologia Molecular e Doenças Endêmicas - Instituto Oswaldo Cruz, FIOCRUZ, Rio de Janeiro, Brazil. ${ }^{2}$ Laboratório de Química de Proteínas, Departamento de Química, UFRJ, Rio de Janeiro, Brazil. ${ }^{3}$ Laboratório de Pesquisa em Leishmaniose - Instituto Oswaldo Cruz, FIOCRUZ, Av. Brasil 4365, Manguinhos, Pav. 26, Sala 509, Rio de Janeiro, Brazil. ${ }^{4}$ Departamento de Medicina, Faculdade de Medicina - Universidade Federal de São João Del Rey, São João del Rei, MG, Brazil.}

Received: 23 February 2015 Accepted: 20 May 2015

Published online: 29 May 2015

\section{References}

1. Sinka ME, Rubio-Palis Y, Manguin S, Patil AP, Temperley WH, et al. The dominant Anopheles vectors of human malaria in the Americas: occurrence data, distribution maps and bionomic précis. Parasit Vectors. 2010;3:72.
2. Laubach HE, Validum L, Bonilla JA, Agar A, Cummings R, Mitchell C, et al. Identification of anopheles aquasalis as a possible vector of malaria in Guyana, south America. West Indian Med J. 2001;50:319-21.

3. Pina-Costa A, Brasil P, Di-Santi SM, Araujo MP, Suárez-Mutis MC, Santelli AC, et al. Malaria in Brazil: what happens outside the Amazonian endemic region. Mem Inst Oswaldo Cruz. 2014;109:618-33.

4. Gallup JL, Sachs JD. The economic burden of malaria. Am J Trop Med Hyg. 2001;64:85-96.

5. Sachs J, Malaney P. The economic and social burden of malaria. Nature. 2002:415:680-5.

6. WHO - Word Health Organization. World Malaria Report 2013. 2013.

7. Hemingway J, Ranson H. Insecticide resistance in insect vectors of human disease. Annu Rev Entomol. 2000;45:371-91.

8. White NJ. Antimalarial drug resistance. J Clin Invest. 2004;113:1084-92.

9. Catteruccia F. Malaria vector control in the third millennium: progress and perspectives of molecular approaches. Pest Manag Sci. 2007;63:634-40.

10. Raghavendra K, Barik TK, Reddy BP, Sharma P, Dash AP. Malaria vector control: from past to future. Parasitol Res. 2011;108:757-79.

11. Chertemps T, Mitri C, Perrot S, Sautereau J, Jacques JC, Thiery I, et al. Anopheles gambiae PRS1 modulates Plasmodium development at both midgut and salivary gland steps. PLoS One. 2010;5, e11538.

12. Blandin S, Shiao SH, Moita LF, Janse CJ, Waters AP, Kafatos FC, et al. Complement-like protein TEP1 is a determinant of vectorial capacity in the malaria vector Anopheles gambiae. Cell. 2004;116:661-70.

13. Osta MA, Christophides GK, Kafatos FC. Effects of mosquito genes on Plasmodium development. Science. 2004;303:2030-2.

14. Yassine H, Kamareddine L, Chamat S, Christophides GK, Osta MA. A serine protease homolog negatively regulates TEP1 consumption in systemic infections of the malaria vector Anopheles gambiae. J Innate Immun. 2014;6:806-18.

15. Gorman MJ, Paskewitz SM. Serine proteases as mediators of mosquito immune responses. Insect Biochem Mol Biol. 2001;31:257-62.

16. Shahabuddin M, Lemos FJA, Kaslow DC, Jacobs-Lorena M. Antibodymediated inhibition of Aedes aegypti midgut trypsins blocks sporogonic development of Plasmodium gallinaceum. Infect Immun. 1996;64:739-43.

17. Rios-Velásquez CM, Martins-Campos KM, Simões RC, Izzo T, dos Santos EV, Pessoa FAC, et al. Experimental Plasmodium vivax infection of key Anopheles species from the Brazilian Amazon. Malar J. 2013;12:460-9.

18. Rawlings ND, Tolle DP, Barrett AJ. MEROPS: the peptidase database. Nucleic Acids Res. 2004;32:160-4.

19. Polgár L. The catalytic triad of serine peptidases. Cell Mol Life Sci. 2005;62:2161-72.

20. Rawlings ND, Barrett AJ. Families of serine peptidases. Methods Enzymol. 1994;244:19-61.

21. Lu SJ, Pennington JE, Stonehouse AR, Mobula MM, Wells MA. Reevaluation of the role of early trypsin activity in the transcriptional activation of the late trypsin gene in the mosquito Aedes aegypti. Insect Biochem Mol Biol. 2006;36:336-43.

22. Shen Z, Edwards MJ, Jacobs-Lorena M. A gut-specific serine protease from the malaria vector Anopheles gambiae is downregulated after blood ingestion. Insect Mol Biol. 2000;9:223-9.

23. Terra WR, Ferreira C. Insect digestive enzymes: properties, compartmentalization and function. Comp Biochem Physiol B. 1994;109:1-62.

24. Wu DD, Wang GD, Irwin DM, Zhang YP. A profound role for the expansion of trypsin-like serine protease family in the evolution of hematophagy in mosquito. Mol Biol Evol. 2009;26:2333-41.

25. Shahabuddin M, Costero A. Spatial distribution of factors that determine sporogonic development of malaria parasites in mosquitoes. Insect Biochem Mol Biol. 2001;31:231-40.

26. Telleria EL, Araújo APO, Secundino NF, d'Avila-Levy CM, Traub-Csekö YM. Trypsin-like serine proteases in Lutzomyia longipalpis - expression, activity and possible modulation by Leishmania infantum chagasi. PLoS One. 2010;5:e10697

27. Molina-Cruz A, Gupta L, Richardson J, Bennett K, Black 4th W, Barillas-Mury C. Effect of mosquito midgut trypsin activity on dengue-2 virus infection and dissemination in Aedes aegypti. Am J Trop Med Hyg. 2005;72:631-7.

28. Paskewitz SM, Andreev O, Shi L. Gene silencing of serine proteases affects melanization of Sephadex beads in Anopheles gambiae. Insect Biochem Mol Biol. 2006;36:701-11.

29. Volz J, Muller HM, Zdanowicz A, Kafatos FC, Osta MA. A genetic module regulates the melanization response of Anopheles to Plasmodium. Cell Microbiol. 2006;8:1392-405. 
30. Mancini E, Tammaro F, Baldini F, Via A, Raimondo D, George P, et al. Molecular evolution of a gene cluster of serine proteases expressed in the Anopheles gambiae female reproductive tract. BMC Evol Biol. 2011;11:72-89.

31. Hörler $\mathrm{E}$, Briegel $\mathrm{H}$. Proteolytic enzymes of female Anopheles: biphasic synthesis, regulation and multiple feeding. Arch Insect Biochem Physiol. 1995;28:189-205.

32. Lemos FJA, Cornel AJ, Jacobs-Lorena M. Trypsin and aminopeptidase gene expression is affected by age and food composition in Anopheles gambiae. Insect Biochem Mol Biol. 1996;26:651-8.

33. Müller HM, Catteruccia F, Vizioli J, della Torre A, Crisanti A. Constitutive and blood meal-induced trypsin genes in Anopheles gambiae. Exp Parasitol. 1995;81:371-85.

34. Saboia-Vahia L, Borges-Veloso A, Cuervo P, Junqueira M, Mesquita-Rodrigues C, Britto $C$, et al. Protein expression in the midgut of sugar-fed Aedes albopictus females. Parasit Vectors. 2012;5:290-314.

35. Galán JE, Pace J, Hayman MJ. Involvement of the epidermal growth factor receptor in the mammalian cells by Salmonella typhimurium. Nature. 1992;357:588-9.

36. Cuervo P, Mesquita-Rodrigues C, D'avila Levy CM, Britto C, Pires FA, Gredilha R, et al. Serine protease activities in Oxysarcodexia thornax (Walker) (Diptera: Sarcophagidae) first instar larva. Mem Inst Oswaldo Cruz. 2008:103:504-6.

37. Caballero NG, Rodríguez-Vega A, Dias-Lopes G, Valenzuela JG, Ribeiro JM, Carvalho PC, et al. Expression of the mevalonate pathway enzymes in the Lutzomyia longipalpis (Diptera: Psychodidae) sex pheromone gland demonstrated by an integrated proteomic approach. J Proteomics. 2014;96:117-32

38. Carvalho PC, Yates 3rd JR, Barbosa VC. Analyzing shotgun proteomic data with patternLab for proteomics. Curr Protoc Bioinformatics. 2010;30:13.13.1-15.

39. Carvalho PC, Fischer JSG, Xu T, Cociorva D, Balbuena TS, Valente RH, et al. Search engine processor: filtering and organizing peptide spectrum matches. Proteomics. 2012;12:944-9.

40. Sievers F, Wilm A, Dineen D, Gibson TJ, Karplus K, Li W, et al. Fast, scalable generation of high-quality protein multiple sequence alignments using Clustal Omega. Mol Syst Biol. 2011;7:539.

41. Sigrist CJ, de Castro E, Cerutti L, Cuche BA, Hulo N, Bridge A, et al. New and continuing developments at PROSITE. Nucleic Acids Res. 2013:41:344-7.

42. Petersen TN, Brunak S, von Heijne G, Nielsen H. SignalP 4.0: discriminating signal peptides from transmembrane regions. Nat Methods. 2011;8:785-6.

43. Caroci AS, Calvo E, Ribolla PE, De Biachi AG, Marinotti O. Two digestive trypsins occur in three species of neotropical anophelines. J Med Entomol. 2003:40:991-5

44. de Almeida RW, Tovar FJ, Ferreira II, Leoncini O. Chymotrypsin genes in the malaria mosquitoes Anopheles aquasalis and Anopheles darlingi. Insect Biochem Mol Biol. 2003:33:307-15.

45. Bahia AC, Kubota MS, Tempone AJ, Pinheiro WD, Tadei WP, Secundino NFC, et al. Anopheles aquasalis infected by Plasmodium vivax displays unique gene expression profiles when compared to other malaria vectors and plasmodia. PLoS One. 2010;5:e9795

46. Costa-da-Silva AL, Marinotti O, Ribeiro JMC, Silva MCP, Lopes AR, Barros MS, et al. Transcriptome sequencing and developmental regulation of gene expression in Anopheles aquasalis. PLoS Negl Trop Dis. 2014;8:e3005.

47. Devenport M, Fujioka H, Jacobs-Lorena M. Storage and secretion of the peritrophic matrix protein Ag-Aper1 and trypsin in the midgut of Anopheles gambiae. Insect Mol Biol. 2004;13:349-58.

48. Giannoni F, Müller HM, Vizioli J, Catteruccia F, Kafatos FC, Crisanti A. Nuclear factors bind to a conserved DNA element that modulates transcription of Anopheles gambiae trypsin genes. J Biol Chem. 2001;276:700-7.

49. Noriega FG, Pennington JE, Barillas-Mury C, Wang X, Wells MA. Early trypsin, an Aedes aegypti female specific protease, is post-transcriptionally regulated by the blood meal. Insect Mol Biol. 1996;5:25-9.

50. Brandon MC, Pennington JE, Isoe J, Zamora J, Schillinger AS, Miesfeld RL. TOR signaling is required for amino acid stimulation of early trypsin protein synthesis in the midgut of Aedes aegypti mosquitoes. Insect Biochem Mol Biol. 2008:38:916-22.

51. Müller HM, Crampton JM, della Torre A, Sinden R, Crisanti A. Members of a trypsin gene family in Anopheles gambiae are induced in the gut by blood meal. EMBO J. 1993;12:2891-900.

52. Saboia-Vahia L, Cuervo P, Borges-Veloso A, Souza NP, Britto C, Lopes GD, et al. The midgut of Aedes albopictus females expresses active trypsin-like serine peptidases. Parasit Vectors. 2014;7:253.
53. Nauen R, Sorge D, Sterner A, Borovsky D. TMOF-like factor controls the biosynthesis of serine proteases in the larval gut of Heliothis virescens. Arch Insect Biochem Physiol. 2001;47:169-80

54. Vandooren J, Geurts N, Martens E, Van den Steen PE, Opdenakker G. Zymography methods for visualizing hydrolytic enzymes. Nat Methods. 2013;10:211-20

55. Mesquita-Rodrigues C, Saboia-Vahia L, Cuervo P, Levy CM, Honório NA, Domont $\mathrm{GB}$, et al. Expression of trypsin-like serine peptidases in pre-imaginal stages of Aedes aegypti (Diptera: Culicidae). Arch Insect Biochem Physiol. 2011;76:223-35

56. Borges-Veloso A, Saboia-Vahia L, Cuervo P, Pires RC, Britto C, Fernandes N, et al. Proteolytic profiling and comparative analyses of active trypsin-like serine peptidases in preimaginal stages of Culex quinquefasciatus. Parasit Vectors. 2012;5:123

57. Filippova M, Ross LS, Gill SS. Cloning of the V-ATPase B subunit cDNA from Culex quinquefasciatus and expression of the $B$ and $C$ subunits in mosquitoes. Insect Mol Biol. 1998;7:223-32

58. Corena MDP, VanEkeris L, Salazar MI, Bowers D, Fiedler MM, Silverman D, et al. Carbonic anhydrase in the adult mosquito midgut. J Exp Biol. 2005;208:3263-73.

59. Okuda K, Caroci AS, Ribolla PEM, de Bianchi AG, Bijovsky AT. Functional morphology of adult female Culex quinquefasciatus midgut during blood digestion. Tissue Cell. 2002;34:210-9.

60. Angulo-Valadez CE, Cepeda-Palacios R, Ascencio F, Jacquiet P, Dorchies P Romero MJ, et al. Proteolytic activity in salivary gland products of sheep bot fly (Oestrus ovis) larvae. Vet Parasitol. 2007;149:117-25.

61. Elpidina EN, Tsybina TA, Dunaevsky YE, Belozersky MA, Zhuzhikov DP, Oppert B. A chymotrypsin-like proteinase from the midgut of Tenebrio molitor larvae. Biochimie. 2005;87:771-9.

62. Tsybina TA, Dunaevsky YE, Belozersky MA, Zhuzhikov DP, Oppert B, Elpidina EN. Digestive proteinases of yellow mealworm (Tenebrio molitor) larvae: purification and characterization of a trypsin-like proteinase. Biochemistry. 2005;70:300-5.

63. Robich RM, Denlinger DL. Diapause in the mosquito Culex pipiens evokes a metabolic switch from blood feeding to sugar gluttony. Proc Natl Acad Sci U S A. 2005:44:15912-7.

\section{Submit your next manuscript to BioMed Central and take full advantage of:}

- Convenient online submission

- Thorough peer review

- No space constraints or color figure charges

- Immediate publication on acceptance

- Inclusion in PubMed, CAS, Scopus and Google Scholar

- Research which is freely available for redistribution

Submit your manuscript at www.biomedcentral.com/submit 